\title{
Essential oils found in the smoke of "tira-capeta", a cigarette used by some quilombolas living in pantanal wetlands of Brazil
}

\author{
Giuseppina Negri,* Eliana Rodrigues
}

\author{
Department of Psychobiology, Federal University of São Paulo Botucatu Street, 862, Ed. Ciências Biomédicas, \\ $1^{\circ}$ andar, 04023-062 São Paulo-SP, Brazil.
}

\begin{abstract}
RESUMO: "Óleos essenciais encontrados na fumaça do "tira-capeta”, um cigarro utilizado pelos quilombolas que vivem no pantanal do Brasil". Pesquisa etnofarmacológica realizada entre os quilombolas que vivem na Sesmaria Mata-Cavalos, no Estado de Mato Grosso, Brasil, um cigarro conhecido como "tira-capeta", foi citado por melhorar a memória e cognição, além de possuir outras indicações terapêuticas, tais como, "contra a sinusite", "para evitar resfriado", e "para aliviar problemas de insônia". No presente estudo, foi feita a caracterização dos óleos essenciais liberados durante o aquecimento das plantas utilizadas na confecção do cigarro, usando um método simples, rápido e livre de solvente baseado em cromatografia gasosa acoplada a espectrometria de massas usando "headspace" e microextração em fase sólida. Os principais constituintes encontrados foram 1,8-cineol, cânfora e $\alpha$-pineno. Na tentativa de correlacionar a atividade biológica desses constituintes com as indicações terapêuticas relatadas pelos quilombolas, encontramos vários trabalhos realizados por diversos autores que mostraram que estes óleos possuem atividades similares às indicações terapêuticas relatadas pelos quilombolas.
\end{abstract}

Unitermos: Etnofarmacologia, óleos essenciais, medicina popular, sistema nervoso central, quilombolas, memória.

\begin{abstract}
An ethnopharmacological survey developed among quilombolas living in Sesmaria Mata-Cavalos, in the State of Mato Grosso, Brazil; a cigarette known as "tira-capeta" (removingthe-devil), had been cited mainly "to improve memory and cognition", and also showed other therapeutical indications, such as: "against sinusitis", "to avoid cold", "to relieve sleep problems". The purpose of the present study was carried out a screening of essential oils delivered in the heating of plants used to produce the "tira-capeta" cigarette, using a simple, rapid and solvent-free method based on gas chromatography-mass spectrometry and headspace solid-phase microextraction. The principal essential oils found were 1,8 cineole, camphor and $\alpha$-pinene. In the tentative to correlate these constituents with therapeutical indications reported by the quilombolas, were found some works carried out by many authors that corroborated the therapeutical indications reported by the quilombolas.
\end{abstract}

Keywords: Ethnopharmacology, essential oils, traditional use, central nervous system, quilombolas, memory.

\section{INTRODUCTION}

Few ethnopharmacological surveys among Quilombolas (descendants of Afro-Brazilian runaway slaves) have been conducted in Brazil, despite the existence of 178 Quilombola's communities in its territory (Fundação Cultural Palmares, 2008). Some exceptions are the studies carried out by Albuquerque (2001) and by Rodrigues \& Carlini (2004).

The use of a great number of plants in a single prescription is very common among Quilombola's therapeutic practice; being also observed among the river dwellers from Brazilian Amazon (Rodrigues, 2006) also in Ayurveda and Chinese therapeutics (Patwardhan et al., 2005). This practice may produce synergistic or antagonistic effects (Gilbert \& Alves, 2003; Rodrigues \& Carlini, 2004).

Plants belonging to tonics for the brain's category are utilized to improve memory and/or cognition; nine out of thirteen plants cited in this category are used as a cigarette known as "tira-capeta" (removing-the-devil). This cigarette is recommended for persons suffering from nervous breakdown due to overwork, being also used by teenagers and children to improve their performance in learning abilities (Rodrigues et al., 2008).

Although the main use of the "tira-capeta" cigarette is as tonic for the brain, it also has other indications, such as: against sinusitis, to gastrointestinal disorders, to avoid 
cold, to relieve sleep problems and to diminish the use of cannabis. In a previous work (Rodrigues et al., 2008), an hydroalcoholic extract (ETC) of "tira-capeta" cigarette was submitted to pharmacological and phytochemical investigations. The phytochemical screening indicated the presence of tannins, phenolic acids, flavonoids, saponins and alkaloids; tannins and phenolic acids being the main components. The pharmacological tests showed that ETC induced a biphasic effect, with intense initial stimulation of CNS, followed by a general depressor state; decreased the latency for sleeping and increased the total sleeping time, without causing prejudice in motor coordination. The purpose of the present study was carried out a screening of essential oils delivered in the heating of plants used to produce "tira-capeta" cigarette, since the route of administration utilized by Quilombolas is the inhalation of the smoke produced by the burning of a cigarette. Gas chromatography-mass spectrometry and headspace solidphase microextraction had been successfully applied for the analysis of essential oils in various medicine plants. Below it will be presented the plants used in the preparation of this cigarette.

Petiveria alliacea L., Phytolaccaceae, grows in all regions of Brazil where it is known by many vernacular names; among them: "erva-guiné", "guiné", "pipi” and "tipi" and "macuracaá", by the Guarani Indians. It is popularly used in folk medicine for treating a wide variety of disorders. In the State of Minas Gerais the roots of this plant are used to treat rheumatism (Gomes et al., 2005) and in other Brazilian regions, both the roots and the leaves are popularly used as stimulant. Phytochemical analysis revealed the presence of coumarins, triterpenes and flavonoids (Rocha \& Da Silva, 1969) amino acids and trisulphide (Kim et al., 2006). So far, there is not information about essential oils.

Eucalyptus globulus Labill., Myrtaceae, is a native dicotyledonous tree of Southeast Australia States, that was introduced in Latin America. E. globulus is one of the most interesting species among the more than 600 species comprising the genus Eucalyptus (Hasegawa et al., 2008). In Brazil this genus also has a great therapeutical importance and several species of Eucalyptus are used in traditional medicine as antiseptics, and against infections of the upper respiratory tract, such as the common cold, influenza and sinus congestion; besides this exhibit antibacterial, analgesic and anti-inflammatory activities (Silva et al., 2003). Essential oil from these species has a therapeutic application in treatment of pulmonary infections by inhalation (Ramezani et al., 2002). Phytochemical analysis showed that the profile of the terpenoids varies among the Eucalyptus species, with potential variations in medicinal properties. The major components identified were aromadendrene, followed by $\alpha$-phellandrene, 1,8-cineole, ledene and globulol (Pereira et al., 2005). In general, all the oils of Eucalyptus species contain $\alpha$-pinene, $\beta$-pinene, $\beta$-caryophyllene and 1,8-cineole as major components
(Sacchetti et al., 2005).

In Brazil, several plants known as "catuaba" are recognized for their aphrodisiac and stimulant properties. One of the species available in Brazilian commerce, traded as "catuaba", was identified as Anemopaegma arvense (Vell.), Bignoniaceae. In the ethyl acetate extract of the stem bark of this plant were found catuabin A and known flavan-3-ol type phenylpropanoids, which possess antioxidant activities (Tabanca et al., 2007). So far, there is not information about essential oils of this plant.

Siparuna guianensis Aubl., Monimiaceae, is a genus of small trees or shrubs that occurs in the neotropics from Vera Cruz, Mexico, until tropical South America. This plant was known as "capitiú" or "negramina" and had been utilized as anxiolytic by South American Indians and "caboclos" river-dwellers (Rodrigues, 2006; Rodrigues et al., 2008). Alkaloids, steroids (Braz Filho et al., 1976), flavonoids (Leitão et al., 2005) and essential oils are found in this plant. Essential oils epi- $\alpha$-cadinol as the major component, except for the fruit and stem bark oils that contained 2-undecanone and terpinolene as main constituents, respectively (Viana et al., 2002). Curzerenone and its derivative were also found in essential oil from leaves (Antonio et al., 1984). The fruit oil consisted mainly of 2-undecanone, $\beta$-pinene and limonene (Fischer et al., 2005).

Ruta graveolens L., Rutaceae, have different established effects like antimicrobial, cytotoxic (Ivanova et al., 2005), fungicide (Meepagala et al., 2005), antiinflammatory (Raghav et al., 2006) and hypotensive properties. It is one of the most ancient and effective contraceptive plants (Maurya et al., 2004; de Freitas et al., 2005). Ketones and alcohols, especially 2-nonanone, 2-undecanone and nonan-2-ol are common in this specie (Fredj et al., 2007, Ivanova et al., 2004). This species possess $\alpha$-pinene, limonene and 1,8-cineole as the main monoterpene constituents. Among other compounds, were detected considerable amounts of valeric acid, octanoic acid and methyl salicylate (De Feo et al., 2002).

Syzygium aromaticum (L.) Merr., Myrtaceae, also known as clove tree, is a perennial tropical plant used as a source for obtaining an essential oil, extracted from the dried flower buds. Clove bud oils showed antibacterial, antifungal, and antioxidant properties, and had been used traditionally as flavoring agent and antimicrobial material in food (Velluti et al., 2003). The main constituents of its essential oil are phenylpropanoids such as carvacrol, thymol, eugenol and cinnamaldehyde (Chaieb et al., 2007), followed by $\beta$-caryophyllene, $\alpha$-humulene, and eugenyl acetate (Park \& Shin, 2005; Jirovetz et al., 2006).

Allium sativum L., Liliaceae, garlic had been used worldwide as a food and medicinal plant since ancient times, and their biological effects have been attributed to its characteristic organosulfur compounds. Garlic is also known as an anticancer, antiseptic, tonic, bactericide, expectorant, stomachic, and antihypertensive. 
Garlic essential oils are reported to consist primarily of diallyl, dimethyl, and allylmethyl mono-, di-, trisulfides (Park \& Shin, 2005; Chung et al., 2007). Allicin (diallyl thiosulfinate) is the main biologically active compound of fresh garlic juice (Camargo et al., 2007).

Plants of Hyptis spp. are recommended in folk medicine for various conditions, among them nasal congestion, skin diseases, gastric disorders, fever, and pain. Bicyclogermacrene, 1,8-cineole, $\alpha$-pinene and $\beta$-caryophyllene are the major components found in Hyptis fruticosa essential oil (Menezes et al., 2007). So far, there is not information about the essentials oils of Hyptis cana Pohl ex Benth (Lamiaeae).

Several Dorstenia species "carapiá" are used in folk medicine, mainly against skin diseases, because of the presence of biologically active compounds. These plants are distributed in the subtropical regions of the world, and they are known by their ability to synthesize furocoumarins. The genus Dorstenia is used in the medicinal plant therapy in many countries as antiophidic and anti-rheumatic, and against infections and skin diseases (Cardoso et al., 2002). So far, there is not information about the essentials oils of Dorstenia asaroides Hook (Moraceae).

\section{MATERIAIS AND METHODS}

\section{Fieldwork}

Ethnopharmacological study was approved by the Ethics Committee on Research of Federal University of São Paulo (n. 056/00) and residents of Sesmaria signed a written consent form to access Quilombola knowledge and botanical material. Samples of each plant mentioned by the interviewees were collected in compliance with methods recommended by Lipp (1989) and the plants were identified at the Botanical Institute of São Paulo (IB), where the vouchers were deposited. The phytochemical study was also approved by Ethics Committee on Research (n. 0147/07).

\section{Botanical material}

Parts of the nine plants used to prepare "tiracapeta" cigarette were collected in Sesmaria MataCavalos by one of the researchers (ER) accompanied by one of the interviewee, the spiritual and political leader, Mr. Cezário. The leaves of the following plants [their respective vouchers] were collected: "guiné" Petiveria alliacea L., Phytolaccaceae [E.Rodrigues 823], "eucalipto" - Eucalyptus globulus Labill., Myrtaceae [E.Rodrigues 525], "alecrim-do-norte" - Anemopaegma arvense (Vell.) Stellfeld ex de Souza, Bignoniaceae [E.Rodrigues 519], "negramina" - Siparuna guianensis Aubl., Monimiaceae [E.Rodrigues 531], "arruda" - Ruta graveolens L., Rutaceae, and "hortelã-da-várzea" - Hyptis cana Pohl ex Benth, Lamiaeae [E.Rodrigues 530]. Also, the rhizomes of "caiá-piá" - Dorstenia asaroides Hook., Moraceae [E.Rodrigues 878]), the flowers of "cravo-daíndia" - Syzygium aromaticum (L.) Merr. \& L.M. Perry, Myrtaceae, and skin of one bulb of garlic - Allium sativum L., Liliaceae. After collection, the respective parts were cut in small pieces, mixed and exposed to the sun.

\section{Analytical procedure}

The procedure was based on methodology published by Polzin et al. (2007) with modifications. Aliquot of $4 \mathrm{~g}$ (approximately $10 \mathrm{~mL}$ ) of powder plants (ground in a grinding Mill Mesh 20) was introduced in the $20 \mathrm{~mL}$ headspace-vials (glass vials for headspace analysis crimped by $20 \mathrm{~mm}$ Teflon/silicone septa), sampling by automated headspace solid-phase microextraction (SPME), closed hermetically and placed into the oven. In the optimized conditions, the sample was heated at $150{ }^{\circ} \mathrm{C}$ for $30 \mathrm{~min}$. The headspace sample was thermally desorbed from the SPME fiber upon insertion in the GC. The needle (heated at $150{ }^{\circ} \mathrm{C}$ ) of the autosampler syringe, once entered the vial and filled the syringe, injected $0.8 \mathrm{~mL}$ of headspace sample directly into the injector liner, which was heated at $200{ }^{\circ} \mathrm{C}$, and led it directly into the ionisation chamber of the mass spectrometer, using nitrogen as cleaning inert gas. Then, a helium stream carried the volatiles through the transfer line, heated at $250{ }^{\circ} \mathrm{C}$, to the mass detector Shimadzu GCMS-QP505A gas chromatograph coupled to a quadrupole mass selective spectrometer and with split of 2. The direct interface between the injector and the detector is ensured by a transfer line, which consists of a $15 \mathrm{~cm}$ long empty retention gap placed in an oven with a temperature controller. Helium was the carrier gas, at a linear velocity of $1.8 \mathrm{~mL} / \mathrm{min}$. The separation of compounds was performed on DB-5 (Shimadzu, Br) capillary column $(30 \mathrm{~m} \times 0.25 \mathrm{~mm}$ internal diameter and $0.25 \mu \mathrm{m}$ film thickness). The initial oven temperature was $40^{\circ} \mathrm{C}$, held for 4 min, ramped at 4 ${ }^{\circ} \mathrm{C} \min ^{-1}$ to $200{ }^{\circ} \mathrm{C}$, held at $200{ }^{\circ} \mathrm{C}$ for $1 \mathrm{~min}$, and ramped at $4{ }^{\circ} \mathrm{C} \min ^{-1}$ to $250{ }^{\circ} \mathrm{C}$ and held for $2 \mathrm{~min}$. The quadrupole mass spectrometer was operated in the electron ionization mode at $70 \mathrm{eV}$ of electron energy, a source temperature of $200{ }^{\circ} \mathrm{C}$, quadrupole temperature of $200{ }^{\circ} \mathrm{C}$, and the transfer line was $250^{\circ} \mathrm{C}$, with a continuous scan from $\mathrm{m} / \mathrm{z} 40$ to 500. The total GC run time was $19.15 \mathrm{~min}$. Constituents were identified by comparing their mass spectra with those reported in the GC/MS computer database (Wiley 275, Wiley 229 and NIST 21) and reference compounds. The relative amounts of the individual components were obtained from GC analysis, based on peak areas without Flame Ionization Detector factor correction.

\section{RESULTS AND DISCUSSION}

Chemical composition of essential oils found in the plants used in "tira-capeta" cigarette. 
A simple, rapid and solvent-free method based on gas chromatography-mass spectrometry (GC-MS) using headspace solid-phase microextraction was developed for the analysis of the essential oils. Compared with conventional extraction techniques e.g. steam distillation and solvent extraction, SPME is a simple, sensitive and solvent-free method for the analysis of essential oils. The principal essential oils obtained from mixture of plants that produce a "tira-capeta" cigarette were 1,8 cineol $(52.0 \%)$, camphor (21.7\%) and $\alpha$-pinene (11.5\%), with low amounts of 3-methylbutanal (4.9\%), camphene (3.6\%), trans-caryophyllene (3.7\%), (E,Z)-3,3-dimethyl1,4-hexadiene $(1.8 \%)$ and $\beta$-elemene $(0.5 \%)$. According to Pereira et al. (2005), E. globulus contain $60-90 \%$ of eucalyptol (1,8-cineol), $2.8-24 \%$ of $\alpha$-pinene and 0.0 $5.5 \%$ of $\beta$-caryophyllene. 1,8-Cineole was also found in $R$. graveolens (De Feo et al., 2002). $\alpha$-Pinene was also found in $R$. graveolens (De Feo et al., 2002) and S. guianensis (Fischer et al., 2005). $\beta$-caryophyllene was also found in $S$. aromaticum. A comprehensive profiling of P. alliacea, A. arvense, $H$. can $a$ and $D$. asaroides essential oils has not been reported so far and the source of the others essential oils found in the present study, mainly camphor, is unknown. However, 1,8-cineole, $\alpha$-pinene, and $\beta$-caryophyllene were the major compounds detected in the essential oil of Hyptis fruticosa (Menezes et al., 2007).

As shown in Table 1, these essential oils are known and were identified by their respective mass spectrum, which was compared with literature data and reference compounds. The mass spectrum of 1,8 cineol showed molecular ion at $m / z 154\left(\mathrm{M}^{+}, \mathrm{C}_{10} \mathrm{OH}_{18}, 70\right)$, and fragments at m/z $139\left(\mathrm{M}^{+}-\mathrm{CH}_{3}\right)(70), 111\left[\mathrm{M}^{+}-\mathrm{CH}\left(\mathrm{CH}_{3}\right)_{2}\right]$ (75), 108 (85), 93 (80), 81 (100), while the mass spectrum of $\alpha$-pinene showed molecular ion at $m / z 136\left(\mathrm{M}^{+}, \mathrm{C}_{10} \mathrm{H}_{16}\right.$, $20)$, and fragments at $m / z 121\left(\mathrm{M}^{+}-\mathrm{CH}_{3}\right)(30), 105\left(\mathrm{M}^{+}\right.$$\left.\mathrm{OCH}_{3}\right)(30), 93\left[\mathrm{M}^{+}-\mathrm{CH}\left(\mathrm{CH}_{3}\right)_{2}\right](100), 77$ (50).

For camphor, the mass spectrum showed the molecular ion at $m / z 152\left(\mathrm{M}^{+}, \mathrm{C}_{10} \mathrm{OH}_{16}, 40\right)$, and fragments at $m / z 137\left(\mathrm{M}^{+}-\mathrm{CH}_{3}\right)(5), 108(137-\mathrm{COH})(45), 95(100)$, 81 (75). Camphene showed molecular ion at $m / z 136\left(\mathrm{M}^{+}\right.$, $\left.\mathrm{C}_{10} \mathrm{H}_{16}\right)(10)$, and fragments at $\mathrm{m} / z 121\left(\mathrm{M}^{+}-\mathrm{CH}_{3}\right)(65)$, $107\left(\mathrm{M}^{+}-\mathrm{COH}\right)(40), 93\left[\mathrm{M}^{+}-\mathrm{CH}\left(\mathrm{CH}_{3}\right)_{2}\right](100), 79(50)$, 67 (45). $\beta$-Caryophyllene showed molecular ion at $\mathrm{m} / \mathrm{z}$ $204\left(\mathrm{M}^{+}, \mathrm{C}_{15} \mathrm{H}_{24}, 1\right)$, and fragments at $\mathrm{m} / \mathrm{z} 164(10), 147$ (5), 133 (80), 120 (40), 105 (70), 93 (90), 91 (100), 79 (90). $\beta$-Elemene showed molecular ion at $\mathrm{m} / z 204\left(\mathrm{M}^{+}\right.$, $\left.\mathrm{C}_{15} \mathrm{H}_{24}, 1\right)$, and fragments at $\mathrm{m} / \mathrm{z} 161\left[\mathrm{M}^{+}-\mathrm{CH}\left(\mathrm{CH}_{3}\right)_{2}\right](20)$, $133(20), 119$ (20), 105 (50), 93 (60) 91 (100), 79 (50). For 3-methylbutanal, the mass spectrum showed molecular ion at $m / z 86\left(\mathrm{M}^{+}, \mathrm{C}_{5} \mathrm{OH}_{10}\right)(1)$ and a fragment at $m / z 57$ $\left(\mathrm{M}^{+}-\mathrm{COH}\right)(60)$. For (E,Z)-3,3-dimethyl-1,4-hexadiene, the mass spectrum showed molecular ion at $m / z 110\left(\mathrm{M}^{+}\right.$, $\left.\mathrm{C}_{8} \mathrm{H}_{14}\right)(25)$ and a fragment at $\mathrm{m} / \mathrm{z} 95\left(\mathrm{M}^{+}-\mathrm{CH}_{3}\right)(100)$.

\footnotetext{
Biological activity of essential oils found in this analysis.
}

In the tentative to correlate these constituents with therapeutical indications reported by the Quilombolas, some works were found carried out by many authors, which showed biological activities for these essential oils similar to the therapeutical indications reported by the Quilombolas. Thus, below will be presented the biological activities, described in scientific literature, to the essential oils found in the plants used for produce the "tira-capeta" cigarette, where some correlations tentatively were carried out between these activities and the therapeutical uses reported by the Quilombolas.

Perry et al. (2000) verified that $\alpha$-pinene, 1,8cineole and camphor have uncompetitive and reversible acetylcholinesterase inhibitory activity. It is known that compounds with anticholinesterase properties improved memory and attention in people (Scholey et al., 2008). This pharmacological evidence could be tentatively to explain the main therapeutical indication made to this cigarette: tonic for the brain.

Besides, other uses described by the Quilombolas to "tira-capeta" could be explained using studies already carried out by others authors. The Quilombola's indication "to avoid cold" could be explained by the presence of monoterpenoid components of the oils of Eucalyptus globulus, which are commercially available for the treatment of the common cold and other symptoms of respiratory infections (Cockcroft, 1992). Also, the use "against sinusitis" could have some relation to the presence of 1,8-cineol. According to Juergens et al., (2004) the role of 1,8-cineol to control airway mucus hypersecretion by cytokine inhibition, suggested that long-term treatment with this compound reduce exacerbations in asthma and sinusitis.

Anxiety is widespread and individuals aged between 10 and 25 years are at highest risk for developing an anxiety condition (. Ligands that bind to the benzodiazepine binding site on the gamma-aminobutyric acid receptor type A (GABAA) receptor can attenuate cognition. Anxiolytics act together with the gabaergic receptors facilitating coupling to GABAA, which is the main neurotransmissor inhibitor to the central nervous system (Harris et al., 2008). Aoshima \& Hamamoto (1999) verified that pinene potentiate the response in the presence of GABA at low concentrations, possibly because they bound to the potentiation-site in $\operatorname{GABA}(\mathrm{A})$ receptors and increase the affinity of GABA to the receptors. Also, Deramciclane, a camphor derivative, is an anxiolytic agent with a unique mechanism of action (Naukkarinen et al., 2005; Monostory et al., 2005). 1,8-Cineol showed anticonvulsant and hypnotic activities (Ismail, 2006). Since Quilombolas declared that one of the uses of "tira-capeta" is "to relieve sleep problems", the pharmacological data above could corroborate this use.

Besides the biological activities cited above, that corroborated the use of "tira-capeta" cigarette by Quilombolas, some other biological activities, such as, 
anticonvulsant, antinociceptive and psychoactive were reported for these essential oils.

At anticonvulsant doses, cineol, $\alpha$-pinene and $\beta$-pinene produced sedation and motor impairment (Sayyah et al., 2004). Intraperitoneal administration of 1,8-cineol and caryophyllene significantly increased ambulatory activity in mice, suggesting that these chemicals possess pharmacological actions on behavior (Umezu et al., 2001). Cineole exhibited an antinociceptive activity comparable to that of morphine. Pinene exerted supraspinal antinociceptive actions (Liapi et al., 2007).
$\beta$-Caryophyllene exhibited antinociceptive effect (Menezes et al., 2007) and anti-inflammatory activity in several experiments (Guan et al., 2007; Fu et al., 2007).

Thus, the results obtained in this study showed that the main essential oils found in the plants used in "tiracapeta" cigarette were 1,8-cineol, $\alpha$-pinene and camphor. In the tentative to carry out a correlation among constituents and biological activity of this essential oil using articles published by some authors, was verified that they produce the majority of the effects described by Quilombolas, "to improve memory and/or cognition", "against sinusitis", "to avoid cold" and "to relieve sleep problems".

Table 1. Essential oils found in the smoke of "tira-capeta" cigarette.

\begin{tabular}{|c|c|c|c|c|}
\hline $\begin{array}{c}\text { Rt } \\
(\mathrm{min})\end{array}$ & Content $(\%)$ & Molecular weight & $\begin{array}{l}\text { GC/EIMS fragments } \\
(\mathrm{m} / \mathrm{z}, \%)\end{array}$ & Proposed structure \\
\hline 2.2 & 4.9 & $\mathrm{C}_{5} \mathrm{OH}_{10}-86$ & $86\left(\mathrm{M}^{+}, 1\right), 57\left(\mathrm{M}^{+}-\mathrm{COH}\right)(60) 136\left(\mathrm{M}^{+}, 20\right), 121\left(\mathrm{M}^{+}-\mathrm{CH}_{3}\right)(30)$ & 3-methylbutanal \\
\hline 9.3 & 11.5 & $\mathrm{C}_{10} \mathrm{H}_{16}-136$ & $\begin{array}{l}105\left(\mathrm{M}^{+}-\mathrm{OCH}_{3}\right)(30), 93\left[\mathrm{M}^{+}-\mathrm{CH}\left(\mathrm{CH}_{3}\right)_{2}\right](100), 77(50) \\
136\left(\mathrm{M}^{+}, 10\right), 121\left(\mathrm{M}^{+}-\mathrm{CH}_{3}\right)(65)\end{array}$ & $\alpha$-pinene \\
\hline 9.8 & 3.6 & $\mathrm{C}_{10} \mathrm{H}_{16}-136$ & $\begin{array}{l}107\left(\mathrm{M}^{+}-\mathrm{COH}\right)(40), 93\left[\mathrm{M}^{+}-\mathrm{CH}\left(\mathrm{CH}_{3}\right)_{2}\right](100), 79(50), 67(45) \\
154\left(\mathrm{M}^{+}, 70\right), 139\left(\mathrm{M}^{+}-\mathrm{CH}_{3}\right)(70),\end{array}$ & camphene \\
\hline 13.4 & 51.9 & $\mathrm{C}_{10} \mathrm{OH}_{18}-154$ & $\begin{array}{l}111\left[\mathrm{M}^{+}-\mathrm{CH}\left(\mathrm{CH}_{3}\right)_{2}\right](75), 108(85), 93(80), 81(100) \\
152\left(\mathrm{M}^{+}, 40\right), 137\left(\mathrm{M}^{+}-\mathrm{CH} 3\right)(5),\end{array}$ & 1,8-cineol (eucapyptol) \\
\hline 17.9 & 21.7 & $\mathrm{C}_{10} \mathrm{OH}_{16}-152$ & $108\left(\mathrm{M}^{+}-\mathrm{CH}_{3} \mathrm{COH}\right)(45), 95(100), 81(75)$ & camphor \\
\hline 19.0 & 1.8 & $\mathrm{C}_{8} \mathrm{H}_{14}-110$ & $\begin{array}{l}110\left(\mathrm{M}^{+}, 25\right), 95\left(\mathrm{M}^{+}-\mathrm{CH}_{3}\right)(100) \\
204\left(\mathrm{M}^{+}, 1\right), 164(10), 147(5), 133\end{array}$ & $\begin{array}{l}\text { (E,Z)-3,3-dimethyl-1,4- } \\
\text { hexadiene }\end{array}$ \\
\hline 27.8 & 3.7 & $\mathrm{C}_{15} \mathrm{H}_{24}-204$ & $\begin{array}{l}(80), 120(40), 105(70), 93(90), 91(100), 79(90) \\
204\left(\mathrm{M}^{+}, 1\right), 161\left(\mathrm{M}^{+}-\mathrm{CH}\left(\mathrm{CH}_{3}\right)_{2}\right)\end{array}$ & $\beta$-caryophyllene \\
\hline 28.5 & 0.5 & $\mathrm{C}_{15} \mathrm{H}_{24}-204$ & $(20), 133(20), 119(20), 105(50), 93(60) 91(100), 79(50)$ & $\beta$-elemene \\
\hline
\end{tabular}

\section{ACKNOWLEDGEMENTS}

The authors thank Dr. E.A.Carlini, the members of the Sesmaria Mata-Cavalos, mainly Cezário, Dr. Lúcia Rossi for the taxonomic identification of plant species; also Márcio Nardelli Wandermuren, civil servant of Analytical Center of University of São Paulo - USP, Rafaela Denise Otsuka. This work was supported by grants from Fundação de Amparo à Pesquisa do Estado de São Paulo (FAPESP) and Associação Fundo de Incentivo à Psicofarmacologia (AFIP).

\section{REFERENCES}

Albuquerque UP 2001. The use of medicinal plants by the cultural descendants of African people in Brazil. Acta Farm Bonaerense 20: 139-144.

Antonio TM, Waller GR, Mussinan CJ 1984. Composition of essential oil from the leaves of Siparuna guianensis Aubl. (Monimiaceae). Chem Ind 14: 514-515.

Aoshima H, Hamamoto K 1999. Potentiation of GABA(A) receptors expressed in Xenopus oocytes by perfume and phytoncid. Biosc Biotech Biochem 63: 743-748.

Braz Filho R, Gabriel SJ, Gomes CMR, Gottlieb OR, Bichara MGA, Maia JGS 1976. Oxoaporphine alkaloids from Fusea longifolia and Siparuna guianensis. Phytochemistry
15: $1187-1188$

Camargo AB, Marchevsky E, Luco JM, 2007. QSAR study for the soybean 15-lipoxygenase inhibitory activity of organosulfur compounds derived from the essential oil of garlic. J Agric Food Chem 55: 3096-3103.

Cardoso CAL, Vilegas W, Barison A, Honda NK. 2002. Simultaneous determination of furanocoumarins in infusions and decoctions from "carapia" (Dorstenia species) by high-performance liquid chromatography. $J$ Agric Food Chem 50: 1465-1469.

Chaieb K, Hajlaoui H, Zmantar T, Ben Kahla-Nakbi A, Rouabhia M, Mahdouani K, Bakhrouf A 2007. The chemical composition and biological activity of clove essential oil, Eugenia caryophyllata (Syzigium aromaticum L. Myrtaceae): A short review. Phytother Res 21: 501-506.

Chung I, Kwon SH, Shim ST, Kyung KH 2007. Synergistic antiyeast activity of garlic oil and allyl alcohol derived from alliin in garlic. J Food Sci 72: M437-M440.

Cockcroft DW 1992. Allergen-induced late asthmatic responses and increased airway responsiveness. Allergy Proceed 13: 1-2.

De Feo V, De Simone F, Senatore F 2002. Potential allelochemicals from the essential oil of Ruta graveolens. Phytochemistry 61: 573-578

De Freitas TG, Augusto PM, Montanari T 2005. Effect of Ruta graveolens L. on pregnant mice. Contraception 71: 74- 
77.

Fischer DCH, Limberger RP, Henriques AT, Moreno PRH 2005. Essential oils from fruits and leaves of Siparuna guianensis (Aubl.) Tulasne from southeastern Brazil. J Essent Oil Res 17: 101-102.

Fredj MBH, Marzouk B, Chraief I, Boukef K, Marzouk Z, 2007. Analysis of Tunisian Ruta graveolens L. oils from Jemmel. J Food Agric Environm 5: 52-55.

Fundação Cultural Palmares, 2008. Revista Palmares, Cultura Afro-Brasileira, Ano IV, número 4, Outubro, Brasília, Distrito Federal.

Fu Y, Zu YG, Chen L, Shi XG, Wang Z, Sun S, Efferth T 2007. Antimicrobial activity of clove and rosemary essential oils alone and in combination. Phytother Res 21: 989994.

Gilbert B, Alves LF 2003. Synergy in plant medicines. Curr Med Chem 10: 13-20.

Gomes PB, Oliveira MMD, Nogueira CRA, Noronha EC, Carneiro LMV, Bezerra JNS, Neto MA, Vasconcelos SMM, Fonteles MMF, Viana GSB, De Sousa FCF 2005. Study of antinociceptive effect of isolated fractions from Petiveria alliacea L. (tipi) in mice. Biol Pharm Bull 28: 42-46.

Guan W, Li S, Yan R, Tang S, Quan C 2007. Comparison of essential oils of clove buds extracted with supercritical carbon dioxide and other three traditional extraction methods. Food Chem 101: 1558-1564.

Harris D, Clayton T, Cook J, Sahbaie P, Halliwell RF, Furtmueller R, Huck S, Sieghart W, DeLorey TM 2008. Selective influence on contextual memory: Physiochemical properties associated with selectivity of benzodiazepine ligands at $\mathrm{GABA}(\mathrm{A})$ receptors containing the alpha 5 subunit. J Med Chem 51: 3788-3803.

Hasegawa T, Takano F, Takata T, Niiyama M, Ohta T 2008. Bioactive monoterpene glycosides conjugated with gallic acid from the leaves of Eucalyptus globulus. Phytochemistry 69: 747-753.

Ismail M 2006. 1,8-Cineol showed anticonvulsant and hypnotic activities. Central properties and chemical composition of Ocimum basilicum essential oil. Pharm Biol 44: 619626.

Ivanova A, Mikhova B, Najdenski H, Tsvetkova I, Kostova I 2005. Antimicrobial and cytotoxic activity of Ruta graveolens. Fitoterapia 76: 344-347.

Ivanova A, Kostova I, Navas HR, Villegas J 2004. Volatile components of some Rutaceae species. Zeitschrf Naturforsch C 59: 169-173.

Jirovetz L, Buchbauer G, Stoilova I, Stoyanova A, Krastanov A, Schmidt E 2006. Chemical composition and antioxidant properties of clove leaf essential oil. J Agric Food Chem 54: 6303-6307.

Juergens UR, Engelen T, Racke K, Stober M, Gillissen A, Vetter H 2004. Inhibitory activity of 1,8-cineol (eucalyptol) on cytokine production in cultured human lymphocytes and monocytes. Pulmonary Pharm Theraph 17: 281-287.

Kim S, Kubec R, Musah RA 2006. Antibacterial and antifungal activity of sulfur-containing compounds from Petiveria alliacea L. J Ethnopharmacol 104: 188-192.

Leitão GG, El-Adjiss de Melo WAL, Leitão SG, Brown L 2005. Separation of free and glycosylated flavonoids from Siparuna guianensis by gradient and isocratic CCC. $J$ Liq Chromatogr R Technol 28: 2041-2051.

Liapi C, Anifantis G, Chinou I, Kourounakis AP, Theodosopoulos S, Galanopoulou P 2007. Antinociceptive properties of 1,8-cineole and beta-pinene, from the essential oil of Eucalyptus camaldulensis leaves, in rodents. Planta Med 73: $1247-1254$.

Lipp FJ. 1989. Methods for ethnopharmacological field work. $J$ Ethnopharmacol 25: 139-150.

Maurya R, Srivastava S, Kulshreshta DK, Gupta CM 2004. Traditional remedies for fertility regulation. Curr Med Chem 11: 1431-1450.

Meepagala KA, Schrader KK, Wedge DE, Duke SO. 2005. Algicidal and antifungal compounds from the roots of Ruta graveolens and synthesis of their analogs. Phytochemistry 66: 2689-2695.

Menezes IAC, Marques MS, Santos TC, Dias KS, Silva ABL, Mello ICM, Lisboa ACCD, Alves PB, Cavalcanti SCH, Marcal RM, Antoniolli AR 2007. Antinociceptive effect and acute toxicity of the essential oil of Hyptis fruticosa in mice. Fitoterapia 78: 192-195.

Monostory K, Kohalmy K, Ludanyi K, Czira G, Holly S, Vereczkey L, Urmos I, Klebovich I, Kobori L 2005. Biotransformation of deramciclane in primary hepatocytes of rat, mouse, rabbit, dog, and human. Drug Metabol Disposition 33: 1708-1716.

Naukkarinen H, Raassina R, Penttinen J, Ahokas A, Jokinen R, Koponen H, Lepola U, Kanerva H, Lehtonen L, Pohjalainen T, Partanen A, Maki-Ikola O, Rouru J 2005. Deramciclane in the treatment of generalized anxiety disorder: A placebo-controlled, double-blind, dosefinding study. Eur Neuropsychopharmacol 15: 617-623.

Park IK, Shin SC 2005. Fumigant activity of plant essential oils and components from garlic (Allium sativum) and clove bud (Eugenia caryophyllata) oils against the Japanese termite (Reticulitermes speratus kolbe). J Agric Food Chem 53: 4388-4392.

Patwardhan B, Warude D, Pushpangadan P, Bhatt N 2005. Ayurveda and traditional chinese medicine: a comparative overview. Evid Based Complem Alt Med 2: 465-473.

Pereira SI, Freire CSR, Neto CP, Silvestre AD, Silva AMS 2005. Chemical composition of the essential oil distilled from the fruits of Eucalyptus globulus grown in Portugal. Flav Fragr J 20: 407-409.

Perry N, Houghton PJ, Theobold A, Jenner P, Perry EK 2000. Invitro inhibition of human erythrocyte acetylcholinesterase by Salvia lavandulaefolia essential oil and constituent terpenes. J Pharm Pharmacol 52: 895-902.

Polzin GM, Stanfill SB, Brown CR, Ashley DL, Watson CH 2007. Determination of eugenol, anethole, and coumarin in the mainstream cigarette smoke of Indonesian clove cigarettes. Food Chem Toxicol 45: 1948-1953. 
Raghav SK, Gupta B, Agrawal C, Goswami K, Das HR 2006. Anti-inflammatory effect of Ruta graveolens L. in murine macrophage cells. J Ethnopharmacol 104: 234-239.

Ramezani H, Singh HP, Batish DR, Kohli RK 2002. Antifungal activity of the volatile oil of Eucalyptus citriodora. Fitoterapia 73: 261-262.

Rodrigues E, Carlini EA 2003. Levantamento etnofarmacológico realizado entre um grupo de quilombolas do Brasil. Arquivos Brasileiros de Fitomedicina Científica 1: 8087.

Rodrigues E, Carlini EA 2004. Plants with possible action on the central nervous system used by a quilombola group in Brazil. Phytother Res 18: 748-753.

Rodrigues E 2006. Ethnopharmacology in the Jaú National Park (JNP), state of Amazonas, Brazil. Phytother Res 20: 378391.

Rodrigues E, Gianfratti B, Tabach R, Negri G, Mendes FR 2008. Preliminar investigation of the effects on the Central Nervous System of tira-capeta (removing-the-devil), a cigarette utilized by some Quilombolas living in Brazil. Phytother Res 22: 1248-1255.

Sacchetti G, Maietti S, Muzzoli M, Scaglianti M, Manfredini S, Radice M, Bruni R 2005. Comparative evaluation of 11 essential oils of different origin as functional antioxidants, antiradicals and antimicrobials in foods. Food Chem 91: 621-632.

Sayyah M, Nadjafnia L, Kamalinejad M 2004. Anticonvulsant activity and chemical composition of Artemisia dracunculus L. essential oil. J Ethnopharmacol 94: 283287.

Silva J, Abebe W, Sousa SM, Duarte VG, Machado MIL, Matos ETA 2003. Analgesic and anti-inflammatory effects of essential oils of Eucaliptus. J Ethnopharmacol 89: 277283.

Scholey AB, Tildesley NTJ, Ballard CG, Wesnes KA, Tasker A, Perry EK, Kennedy, DO 2008. An extract of Salvia (sage) with anticholinesterase properties improves memory and attention in healthy older volunteers. Psychopharmacology 198: 127-139.

Tabanca N, Pawar RS, Ferreira D, Marais JPJ, Khan SI, Joshi V, Wedge DE, Khan IA 2007. Flavan-3-ol-phenylpropanoid conjugates from Anemopaegma arvense and their antioxidant activities. Planta Med 73: 1107-1111.

Umezu T, Sakata A, Ito H 2001. Ambulation-promoting effect of peppermint oil and identification of its active constituents. Pharm Biochem Behav 69: 383-390.

Velluti A, Sanchis V, Ramos AJ, Egido J, Marin S 2003. Inhibitory effect of cinnamon, clove, lemongrass, oregano and palmarose essential oils on growth and fumonisin B-1 production by Fusarium proliferatum in maize grain. Internat J Food Microbiol 89: 145-154.

Viana FA, Andrade-Neto M, Pouliquen YBM, Uchoa DEA, Sobral MMSZ, de Morais SM. 2002. Essential oil of Siparuna guianensis Aublet from the Amazon region of Brazil. J Essent Oil Res 14: 60-62. 